\title{
Rape Myth Acceptance In College Students: A Literature Review
}

Rosemary Iconis, Queensborough Community College of the City University of New York

\begin{abstract}
Sexual violence is a common phenomenon in the United States. College women appear to be at an even higher risk than those in the general population. Though there is much we still do not know about the causes of sexual violence, the acceptance of rape myths has been associated with the perpetration of sexual assaults.
\end{abstract}

Keywords: rape myths; college students

\section{INTRODUCTION}

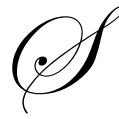

exual violence is a frequent occurrence in the United States. The Federal Bureau of Investigation (2000) estimates that one in four women will be sexually assaulted in her lifetime. Women between 16 and 24 years of age are the most frequently reported victims of rape (U.S. Department of Justice, 2003). Today's college students function in an environment in which rape is a serious social concern. For decades, the feminist movement in the United States has focused considerable public attention on the issue of rape. Still, rape remains a significant social problem. There is much yet to learn about the causes of sexual violence. It is possible that predominant cultural attitudes, at least in part, facilitate continued tolerance of aggression toward women, and thus, the occurrence of sexual violence. Given that sexual violence continues to occur at such high rates in the United States, it is imperative that we understand attitudes and cultural norms that serve to minimize or foster tolerance of sexual violence (Aosved

\& Long, 2006).

\section{RAPE MYTHS}

Rape myths are a specific set of attitudes and beliefs that may contribute to ongoing sexual violence by shifting blame for sexual assault from perpetrators to victims. In 1980 Martha Burt published her ground-braking paper on rape myths (1980). She defined rape myths as "prejudicial, stereotyped, or false beliefs about rape, rape victims, and rapists" (p.217). Burt identified examples of these myths, including "women ask for it" and "rapists are sex-starved, insane, or both" (p.217). Such common rape perceptions represent beliefs that have virtually no factual basis in reality.

Lonsway and Fitzgerald (1994) defined rape myths as "attitudes \& beliefs that are generally false but are widely and persistently held, and that serve to deny and justify male sexual aggression against women" (p.134). Men may use rape myths to justify or deny men's sexual violence and women may use them to deny personal vulnerability to rape. For example, a man may endorse the myth that if a woman does not have bruises, she cannot claim she was raped. He might, then, regard coercing a woman to have sex as acceptable as long as he does not leave bruises on her. If a woman endorses the myth that only promiscuous women get raped, she might feel that she can avoid rape by not "sleeping around." The process of justifying or denying sexual violence or denying personal vulnerability often involves limiting which behaviors are considered to be rape and blaming rape victims for their own victimization (Peterson \& Muehlenharad, 2004).

A number of studies have illustrated that many men and women from varied backgrounds ascribe to rape myths (Lonsway \& Fitzgerald, 1994). Additionally, studies have demonstrated that high rape myth acceptance is 
associated with sexual assaults (Abbey, McAuslan \& Ross, 1998; Koss \& Dinero, 1989). Thus, both perpetrators of sexual assault and people in the general population report beliefs that tolerate and even support sexual violence.

One myth is that rape is a crime of pure passion, meaning that it is primarily sexually motivated. In spite of a great deal of research to the contrary, there is still a tendency to attribute sexual urges as the primary motivating factor for rape (Johnson, Kuck \& Schander, 1997).

Another common myth is that rapists are most often strangers who unexpectedly attack their victims in a dark alley. However, most rapes are committed by someone the victim knows (Department of Justice, 2003). Rape myths are also reflected in the attribution of blame to victims. Victim blame is expressed in several themes: victim masochism (e.g. they enjoy it or want it), victim precipitation (e.g. it only happens to certain types of women), and victim fabrication (e.g. they lie or exaggerate) (Ben-David \& Schneider, 2005).

Other myths deal with the psychological consequences of rape. For example, rape is considered to be less psychologically harmful to the victim when carried out by a steady date, versus a first date or a stranger. In reality, there is no difference in the degree of psychological symptoms between victims who were raped by a stranger, an acquaintance, a spouse, or a family member (Koss, Dinero, Serbel \& Cox, 1988). In addition, the degree of psychological damage and trauma tend to be seen as a function of the victim's sexual experience. Ward (1995) found that $24 \%$ of police officers, $11 \%$ of lawyers, $6 \%$ of doctors, and $3 \%$ of rape counselors thought that sexually experienced women are not really damaged by rape.

\section{RAPE MYTH ACCEPTANCE AND COLLEGE STUDENTS: GENDER ROLE ATTITUDES}

Sexism, characterized by negative attitudes toward women, including their social roles and gender roles, has been extensively examined in relation to rape myth acceptance. A number of studies have demonstrated that negative stereotypical attitudes toward, and beliefs about women, are associated with greater rape myth acceptance. This relationship has been found in both college student samples (Johnson, Kluck \& Schander, 1997: Lonsway \& Fitzgerald, 1994; Holcomb, D.R., Holcomb,L.C., Sondag, R.A. \& Williams, N., 1991; Larson \& Long, 1988) and non-student samples (Costin \& Schwarz, 1987; Burt, 1980).

Men and women have been shown to differ dramatically in their perceptions of and attitudes toward rape, rapists, and rape victims (Tetreault \& Barnett, 1987; Dietz, Littman \& Bentley, 1984). Dietz and colleagues (1984) and Quackenbush (1989) found that male subjects were significantly more likely than female subjects to believe that sex is the primary motivation for rape; female subjects were significantly more likely than male subjects to view power as the primary motivation for rape; and male subjects were significantly more likely than female subjects to attribute more responsibility to the victim of rape and to view rape as less severe than women.

Burt (1980) found that beliefs in rape myths are highly correlated with several attitudinal variables, indicating that there is a relationship between the acceptance of rape myths and such attitudes as gender role stereotyping, distrust of the other gender, and acceptance of interpersonal violence.

Acock and Ireland (1983) found that actions on the part of the victim may be used to justify attributions of blame when victims violated traditional gender role norms, such as hitchhiking alone at night. In such instances, observers blamed the victims more and the rapist less than when the victim's behaviors were inconsistent with traditional gender norms.

Some researchers have speculated that certain behaviors associated with all-male groups might encourage attitudes supportive of sexual aggression. Bleeker and Murnen (2005) found that fraternity men were more likely than non-fraternity men to display sexually degrading images of women in their rooms and that the degree of degradation in the images were correlated with the rape myths held by the men.

Examinations of intercollegiate athletes have found males to be significantly more likely than females to demonstrate a greater acceptance of rape myths (Sawyer, 2002; Syzmanjki, Devlin, Chisler \& Vyse, 1993). In her 
study of intercollegiate athletes, Sawyer (2002) found that both male and female respondents, though predominately males, felt that about half of all reported rapes were invented by women. In other words, it was believed that women lied about being raped $50 \%$ of the time.

Sawyer (2002) found, however, that male athletes are not a homogeneous group. Rape myth acceptance was significantly higher among freshman and sophomore male student athletes than juniors and seniors and athletes participating in individually-focused sports, such as golf, were less accepting of rape myths than those involved in more team-based sports.

\section{RAPE MYTHS PERPETUATE RAPE}

Many rape myths convey two ideas: They define rape much more narrowly than legal definitions (e.g. rape occurs between strangers, involves weapons, requires substantial victim resistance, leaves the victim injured). And rape myths blame victims for rape. Both of these ideas could potentially lead to unacknowledged rape.

Considering the high prevalence of rape in the U.S., one might conclude that social change is necessary. Rape myths, though, can obscure the need for social change. "In considering the function of rape myths in unacknowledged rape, one may conceptualize rape myths as a series of tests any rape would need to pass in order to warrant the conclusion that social change is necessary, e.g. "It is usually only women who dress suggestively who are raped." Thus, if a woman was not dressed suggestively, it was not rape; if she was dressed suggestively, it was her fault. In either case, social change is unnecessary. By arguing against the need for social change, rape myths help to perpetuate rape (Peterson \& Muchlenhard, 2004)."

\section{CONCLUSION}

The purpose of this paper was to examine the current state of rape myth acceptance in college students and the factors which differentiate acceptance versus non-acceptance of rape myths. Alarmingly high rates of acquaintance rape exist in college student populations. Gidyez, Hanson and Layman (1995) found that between $18 \%$ and $21 \%$ of college women reported that they were sexually assaulted during a single academic quarter. Seven percent of these women indicated that they had experienced either an attempted rape or a rape. In addition, women who experienced prior dating violence were at greater risk for revictimization throughout their college years (Smith, White \& Holland, 2003).

Research tells us that individuals who engage in sexually aggressive behavior, particularly rape, subscribe to belief systems that are markedly different from those who refrain from sexually aggressive behavior. Research findings suggest that specific factors such as victim blame, sex role expectations, misinformation, and communication/relationship skills contribute to an individual's potential to subscribe to rape supportive attitudes (Aosved \& Long, 2006; Abbey, McAuslan \& Ross, 1998; Lonsway \& Fitzgerald, 1994; Acock \& Ireland, 1983). The research also suggests that gender and gender attendance at a rape prevention workshop may impact rape myth acceptance. Men and individuals who have not been exposed to rape awareness information disagree less strongly with rape myth statements than women and individuals who have been exposed to rape awareness information. Research on the topic has consistently found that men are more likely to accept rape myths than women (Lonsway \& Fitzgerald, 1994); however, the relationship between attendance at rape workshops and rape myth acceptance is not as clear. The researchers suggest that this may be due to differences among the workshops, e.g. who presents the information (male/female faculty member or male/female peer), how the information is presented (lecture, discussion, video), and to whom the information is presented (all male audience, all female audience, mixed audience) (Hink \& Thomas, 1999).

Rape prevention programs exist on most college and university campuses in the United States (Sochting, Fairbrother \& Koch, 2004; Choate, 2003). Federal funding mandates require that all colleges and universities that receive federal funding must offer some type of rape prevention program. Because of the high rate of sexual assault on college campuses, they may be particularly effective settings for interventions. In addition, college students are being exposed to new ideas, norms, and social groups (Abbey, McAuslan, Zawacki, Clinton, \& Buck, 2001). 
Rape prevention programs vary according to whether the goal is to provide information, influence attitudes, change behaviors, or combine several of those functions. The results of evaluations of existing programs are inconclusive.

Rape prevention programs must find ways to impact the communication patterns and behavior patterns of college students in their everyday interactions. Educators need to acknowledge that different audiences may be impacted by different presentation styles. Existing research offers that men respond best to workshops that are less verbal and didactic and more visually oriented (Harrison, Downes \& Williams, 1991). Earle (1996) offers that the most effective program in changing attitudes is single sex, small interactive groups with discussion rather than lecture as the primary information source.

The alarming number of rapes occurring on college campuses and the lack of evaluation research on programs to decrease rape supportive attitudes, point to the importance of continued research and evaluative efforts.

\section{ABOUT THE AUTHOR}

Dr. Rosemary Iconis is currently an Associate Professor at Queensborough Community College of the City University of New York. She is an award winning lecturer whose papers have been presented both nationally and internationally. Accomplished as a writer and researcher, Dr. Iconis has published extensively for newspapers and magazines on topics related to the health of both children and adults.

\section{REFERENCES}

1. Abbey, A., McAuslan, P., Zawacki, T., Clinton, A.M., and Buck, P.O. (2001). Attitudinal, Experiential, \& Situational Prediction of Sexual Assault Perpetration. Journal of Interpersonal Violence, 16, 784-807.

2. Acock, A.C. and Ireland, N.K. (1983). Attribution of blame in rape cases: The impact of norm violation, gender, and sex-role attitude. Sex Roles, 8, 179-193.

3. Aosved, A. and Long, P. (2006). Co-occurrence of rape myth acceptance, sexism, racism, homophobia, ageism, classicism, and religious intolerance. Sex Roles: A Journal of Research, 55, 1.

4. Ben-David, S. and Schneider, O. (2005). Rape perceptions, gender role attitudes, and victim-perpetrator acquaintance. Sex Roles: A Journal of Research, 55, 385-402.

5. Bleeker, E.T. and Murnen, S.K. (2005). Fraternity membership, the display of degrading images and rape myth acceptance. Sex Roles: A Journal of Research, 53, 487-496.

6. Burt, M.R. (1980). Cultural myths and supports for rape. Journal of Personality and Social Psychology, 38, 217-230.

7. Choate, L.H. (2003). Sexual assault prevention programs for college men: An exploratory evaluation of the men against violence model. Journal of College Counseling, 6, 166-176.

8. Costin, F. and Schwarz, N. (1987). Beliefs about rape and women's social roles. Journal of Interpersonal Violence, 2, 46-56.

9. Deitz, S.R., Littman, M., and Bentley, B.J. (1984). Attribution of responsibility for rape: The influence of observer empathy, victim resistance, and victim attractiveness. Sex Roles, 10, 261-280.

10. Earle, J.P. (1996) Acquaintance rape workshops: Their effectiveness in changing the attitudes of first year men. NAPSA Journal, 34, 2-16.

11. Federal Bureau of Investigation. 2000. The uniform crime reports. Retrieved March 30, 2002, from http://www.fbs.gov/ucr/cius_00/00crime2_4.pdf.

12. Gidycz, C.A., Hanson, K., and Layman, M. (1995). A prospective analysis of the relationship among sexual assault experiences: An extension of previous findings. Psychology of Women Quarterly, 19, 5-29.

13. Hinch, S.S. and Thomas, R.W. (1999). Rape myth acceptance and college students: How far we have come. Sex Roles: A Journal of Research, 815.

14. Harrison, P.J., Downes, J., and Williams, M.D. (1991). Date and acquaintance rape: Perception and attitude change strategy. Journal of College Student Development, 32, 131-139.

15. Holcomb, D.R., Holcomb, C.C., Sondag, K.A., and Williams, N. (1991). Attitudes about date rape: Gender differences among college students. College Student Journal, 25, 434-440. 
16. Johnson, B.E., Kuck, D.C., and Schander, P.R. (1997). Rape myth acceptance and sociodemographic characteristics: A multidimensional analysis. Sex Roles, 36, 693-707.

17. Koss, M.P. and Dinero, T.E. (1989). Discriminate analysis of risk factors for sexual victimization among a national sample of college women. Journal of Counseling and Clinical Psychology, 57, 242-250.

18. Koss, M.P., Dinero, T.E., Seibel, C.A. and Cox, S.C. (1988). Stranger and Acquaintance Rape: Are there differences in the victim's experiences? Psychology of women quarterly, 12, 1-24.

19. Larsen, K.S. and Long, E. (1988). Attitudes toward sex roles: Traditional or egalitarian? Sex Roles, 19, 112.

20. Lonsway, K.A. and Fitzgerald, L.F. (1994). Rape myths: In review. Psychology of Women Quarterly, 18, 133-164.

21. Peterson, Z.D. and Muehlenhard, C.L. (2004) Was it rape? The function of women's rape myth acceptance and definitions of sex in labeling their own experiences. Sex Roles: A Journal of Research, 51, 129+.

22. Quackenbush, R.L., (1989). A comparison of androgynous, masculine sex-typed, and undifferentiated males on dimensions of attitudes toward rape. Journal of Research in Personality, 23, 318-342,

23. Sawyer, R. (2002). Rape myth acceptance among intercollegiate student athletes: A preliminary examination. American Journal of Health Studies, Winter, 1-8.

24. Smith, P.H., White, J.W., and Holland, L.J. (2003). A longitudinal perspective on dating violence among adolescent and college age women. Journal of American College Health, 93, 1104-1109.

25. Sochting, I., Fairbrother, N., and Koch, W.J. (2004) Sexual assault of women: Prevention efforts and risk factors. Violence Against Women, 10,73-93.

26. Syzmanjki, L.A., Devlin, A.S. Chisler, J.C. and Vyse, S.A. (1993). Gender role and attitudes toward rape in male and female college students. Sex Roles, 29, 37-57.

27. Tetreault, P.A. and Barnett, M.A. (1987). Reactions to stranger and acquaintance rape. Psychology of Women Quarterly, 11, 353-358.

28. U.S. Department of Justice (2003). Bureau of Justice Statistics, Criminal Victimization, 2002. Washington, D.C.: U.S. Department of Justice.

29. Ward, C.A. (1995) Attitudes towards rape: Feminist and social psychological perspectives. London: Sage 
NOTES 